\title{
PENGARUH VARIASI KOMPOSISI BIOBRIKET CAMPURAN ARANG KAYU DAN SEKAM PADI TERHADAP LAJU PEMBAKARAN, TEMPERATUR PEMBAKARAN DAN LAJU PENGURANGAN MASA
}

\author{
Subroto, Tri Tjahjono, Andrew MKR \\ Jurusan Teknik Mesin Fakultas Teknik Universitas Muhammadiyah Surakarta \\ Jl. A. Yani Tromol Pos I Pabelan, Kartasura \\ subroto@ums.ac.id
}

\begin{abstract}
ABSTRAK
Disaat harga bahan bakar minyak membumbung semakin tinggi, sebagai alternatif untuk mencari bahan bakar selain minyak maka dilakukan penelitian tentang potensi biomass sekam padi dan arang kayu sebagai sumber energi alternatif, guna diolah menjadi bahan bakar alternatif berupa biobriket dengan komposisi terbaik dan ramah lingkungan.

Dalam penelitian ini komposisi yang di uji adalah biobriket dengan perbandingan prosentase sekam padi : arang kayu $=30 \%: 70 \%, 40 \%: 60 \%, 50 \%: 50 \%$. Penelitian awal dilakukan dengan pengumpulan, penghalusan, pengujian bahan baku dan pencampuran bahan baku, selanjutnya dilakukan pengepresan dengan tekanan 100 $\mathrm{kg} / \mathrm{cm} 2$ kemudian dilakukan pembakaran dengan menggunakan alat yang terdapat di Laboratorium Teknik Mesin UGM untuk mengetahui besarnya laju pengurangan massa dengan kecepatan udara konstan, kemudian dilanjutkan dengan pengujian emisi polutan dan pengujian kadar abu yang juga di lakukan di laboratorium Tehnik Mesin UGM

Berdasarkan percobaan dan parameter yang telah di uji, penambahan biomass menyebabkan naiknya volatile matter sehingga lebih cepat terbakar dan laju pembakaran lebih cepat. Penambahan biomass juga dapat menurunkan emisi polutan yang dihasilkan pada saat pembakaran. Komposisi biobriket terbaik yang dapat digunakan untuk kebutuhan sehari-hari adalah komposisi arang kayu : sekam padi $=50 \%: 50 \%$ karena lebih cepat terbakar dan lebih ramah lingkungan, sedangkan untuk kebutuhan industri, komposisi terbaik dengan pencapaian temperatur tertinggi adalah komposisi arang kayu : sekam padi $=30 \%: 70 \%$.
\end{abstract}

Kata kunci : Arang kayu, Sekam padi, biobriket.

\section{PENDAHULUAN}

Minyak bumi merupakan sumber energi yang tidak dapat diperbaharui. Tetapi minyak bumi merupakan bahan yang menjadi pilihan utama dalam penggunaannya sebagai kebutuhan sehari-hari sebagian besar masyarakat Indonesia. Oleh karena hal itu cadangan minyak bumi akan semakin menipis. Sementara itu masih banyak sumber energi alternatif lain yang masih belum maksimal penggunaannya, untuk dikonsumsi oleh masyarakat. Sesungguhnya di negara Indonesia ini mempunyai banyak potensi dalam pengembangan dan penggunaan energi alternatif.

Beberapa energi alternatif yang biasa digunakan menjadi pengganti minyak bumi 
adalah gas bumi, batubara, arang kayu, serta pengembangan biomass untuk diolah menjadi briket $[1,2]$. Batu bara dan gas bumi merupakan energi fosil dan untuk mendapatkannya, masyarakat menengah ke bawah masih merasa kesulitan. Berdasarkan hal tersebut diatas, untuk memanfaatkan sumber energi alternatif baru yang relatif murah dan dapat dijangkau oleh masyarakat menengah ke bawah.

Biomass merupakan merupakan bahan hayati yang biasanya dianggap sebagai sampah dan sering dimusnahkan dengan cara dibakar. Biomass tersebut dapat diolah menjadi bio arang yang merupakan bahan bakar yang memiliki nilai kalor yang cukup tinggi dan dapat digunakan dalam kehidupan sehari-hari.

\section{BATASAN MASALAH}

Mengingat kompleksnya permasalahan yang timbul pada pembuatan briket sebagai bahan bakar alternatif, maka ruang lingkup yang dibatasi adalah karakterisasi pembakaran biobriket berbahan dasar arang kayu dengan campuran sekam padi yang meliputi laju pembakaran, sebagai akibat perubahan kecepatan udara pembakaran

\section{TUJUAN PENELITIAN}

Tujuan dari penelitian yang dilakukan ini adalah :

1. Mengolah limbah dari hasil pertanian padi yaitu sekam padi yang selama ini kurang maksimal pemanfaatannya menjadi bahan bakar alternatif.

2. Memanfaatkan penggunaan arang kayu yang mempunyai tingkat ekonomis rendah dan banyak sekali terdapat di Indonesia.

3. Menentukan karakter pembakaran briket, termasuk polusi yang ditimbulkan.

\section{KAJIAN PUSTAKA}

\section{Tahapan dalam pembakaran bahan bakar padat [3]}

1. Pengeringan

Dalam proses ini bahan bakar pengalami proses kenaikan temperatur yang akan mengakibatkan menguapnya kadar air yang berada pada permukaan bahan bakar tersebut, sedangkan untuk kadar air yang berada di dalam akan menguap melalui pori-pori bahan bakar padat tersebut.

2. Devolatilisasi

Yaitu proses bahan bakar mulai mengalami dekomposisi setelah terjadi pengeringan.

3. Pembakaran Arang

Sisa dari pirolisis adalah arang (fix carbon) dan sedikit abu, kemudian partikel bahan bakar mengalami tahapan oksidasi arang yang memerlukan $70 \%-80 \%$ dari total waktu pembakaran.

\section{Faktor-faktor yang mempengaruhi pembakaran bahan bakar padat}

1. Ukuran partikel

Partikel yang lebih kecil ukurannya akan lebih cepat terbakar.

2. Kecepatan aliran udara

Laju pembakaran biobriket akan naik dengan adanya kenaikan kecepatan aliran udara dan kenaikan temperatur

3. Jenis bahan bakar

Jenis bahan bakar akan menentukan karakteristik bahan bakar. Karakteristik tersebut antara lain kandungan volatile matter dan kandungan moisture.

4. Temperatur udara pembakaran

Kenaikan temperatur udara pembakaran menyebabkan semakin pendeknya waktu 
pembakaran.

\section{Beberapa masalah yang berhubungan dengan pembakaran sekam padi dengan arang} kayu

- Kadar air

Kandungan air yang tinggi menyulitkan penyalaan dan mengurangi temperatur pembakaran.

- Kadar kalori

Semakin besar nilai kalor maka kecepatan pembakaran semakin lambat.

- Kadar abu

Kadar abu yang tinggi didalam sekam padi tidak mempengaruhi proses pembakaran. Kadar abu yang tinggi dalam sekam padi akan mempersulit penyalaan

- Volatile matter atau zat-zat yang mudah menguap

Semakin banyak kandungan volatile matter pada biobriket maka semakin mudah biobriket untuk terbakar dan menyala.

- Bulk density

Sekam padi mempunyai bulk density yang jauh lebih rendah dibandingkan arang kayu

\section{Jenis polutan yang dihasilkan pada pembakaran bahan bakar [4]}

Secara teoritis pembakaran bahan bakar menghasilkan $\mathrm{CO}_{2}$ dan $\mathrm{H}_{2} \mathrm{O}$ saja, padahal kenyataannya pembakaran pada bahan bakar banyak yang tidak sempurna dimana akan menimbulkan zat-zat polutan yang berbahaya terhadap kesehatan manusia. Adapun beberapa polutan dari bahan bakar antara lain : Sulfur Dioksida $\left(\mathrm{SO}_{2}\right)$, Carbon Monoksida (CO), Oksida nitrogen $\left(\mathrm{NO}_{2}\right)$, Oksidan $\left(\mathrm{O}_{3}\right)$, Hidrokarbon $(\mathrm{HC})$, Khlorin $\left(\mathrm{Cl}_{2}\right)$, Partikel Debu, Timah Hitam $(\mathrm{Pb})$, Besi (Fe).

\section{METODOLOGI PENELITIAN \\ Diagram alir penelitian}

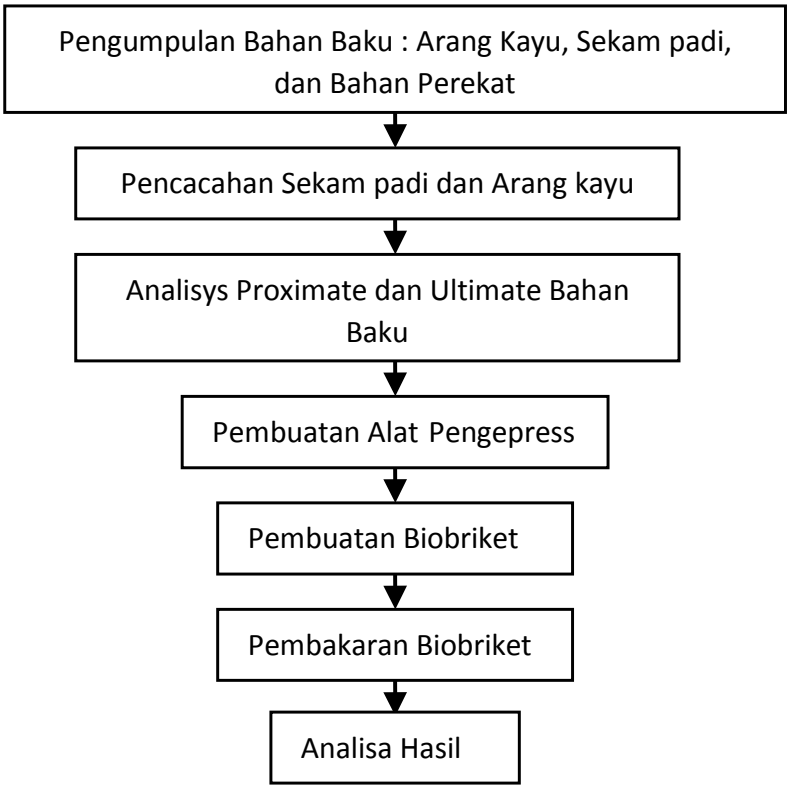

Gambar 1. Flowchart Penelitian

\section{Pengumpulan Dan Pengolahan Bahan Baku}

\section{Bahan Penelitian}


- Arang Kayu

- Sekam padi

- Bahan perekat tepung pati

- Gas LPG, bahan bakar untuk memanaskan tungku pada pembakaran biobriket.

2. Pengolahan Bahan Baku

- Penghalusan arang kayu menjadi serbuk

- Pencacahan sekam padi menjadi serbuk

- Pembuatan bahan perekat

\section{Pembuatan Biobriket}

- Pencampuran bahan baku

Arang kayu, sekam padi dan bahan perekat dicampur hingga rata dengan komposisi Sekam padi : Arang kayu = 30\%: 70\%, 40\%: 60\%, 30\%: 70\%. (dalam penelitian ini prosentase bahan perekat diabaikan dan dianggap homogen ).

- Pencetakan biobriket

Bahan baku yang telah tercampur rata dimasukkan ke dalam cetakan yang berbentuk silinder dengan diameter $1,5 \mathrm{~cm}$ dan tinggi $1,75 \mathrm{~cm}$.

- Pengepresan

Bahan baku dimasukkan ke dalam cetakan, kemudian dilakukan pengepresan dengan tekanan $100 \mathrm{~kg} / \mathrm{cm} 2$ dan didiamkan selama 10 menit. Setelah itu biobriket dikeluarkan dari cetakan dan dikeringkan di tempat yang tidak terkena sinar matahari secara langsung selama 3 hari.

Adapun biobriket yang dihasilkan dapat dilihat pada gambar dibawah ini.

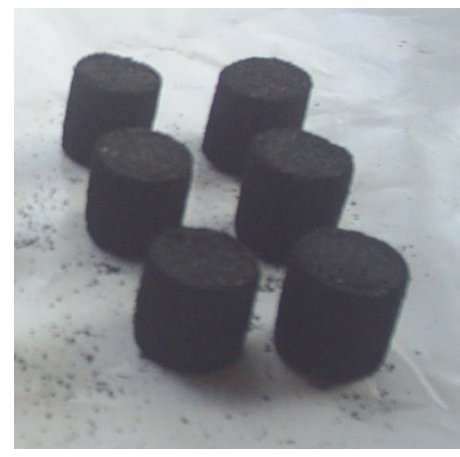

Gambar 2. Biobriket

\section{Peralatan Yang Digunakan}

Peralatan utama yang digunakan dalam penelitian ini terdapat di Laboratorium Teknik Mesin Universitas Muhammadiyah Surakarta :

a. Alat Pembakaran Biobriket

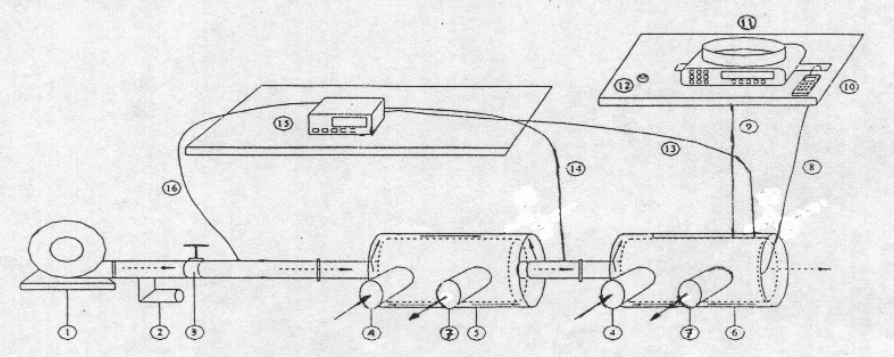

Gambar 3. Sketsa alat uji 
Keterangan :

$\rightarrow$ Aliran pemanas LPG

$\rightarrow$ Aliran udara

1. Blower

2. Saluran by pass

3. Katup pengatur aliran udara

4. Saluran masuk pemanas LPG

5. Tungku 1

6. Tungku 2

7. Saluran buang pemanas LPG

8. Termakopel temperatur dinding

9. Kawat penggantung sampel bahan bakar

10. Digital thermocouple reader

11. Electronic professional scale

12. Stop wacth

13. Termokopel temperatur gas pembakaran

14. Termokopel temperatur udara pre-heater

15. Digital thermocouple reader

16. Termokopel temperatur udara supply

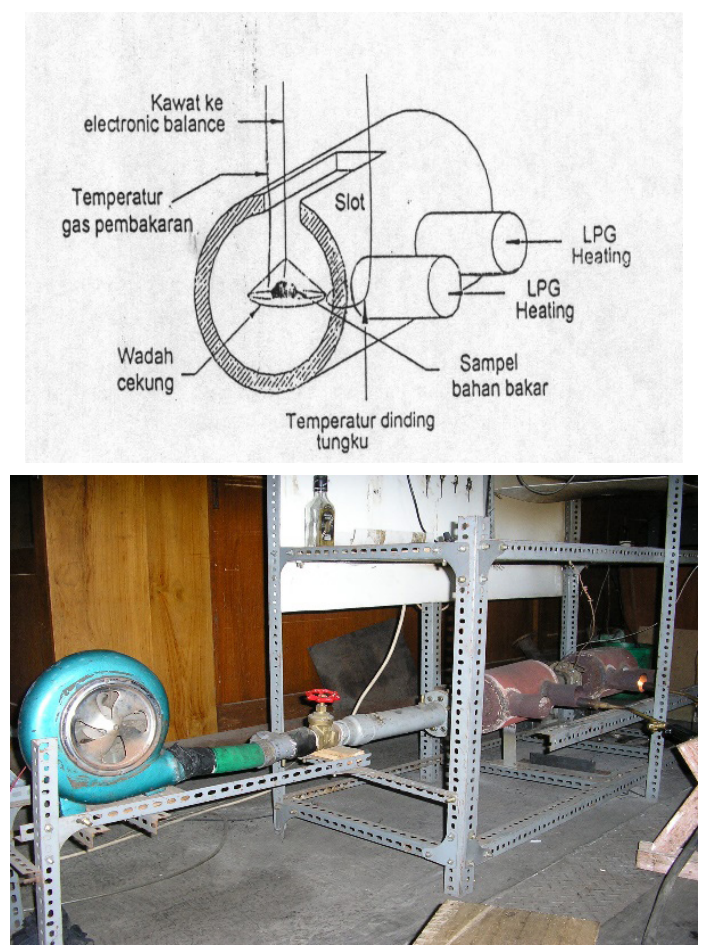

Gambar 4. Tempat pembakaran Biobriket

b. Alat Pengepress biobriket

Alat pengepress biobriket dibuat deangan cara memodifikasi dongkrak hidraulik yang bertekanan maximal 2 ton dengan diameter $22 \mathrm{~mm}$ dan dipasang manometer pada saluran pembuangan udara dongkrak yang berfungsi untuk mengukur tekanan pada saat pengepresan. 


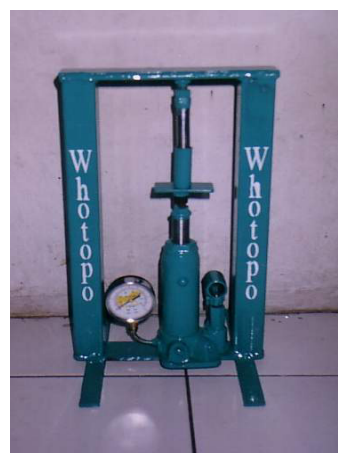

Gambar 5. Alat pengepress Biobriket

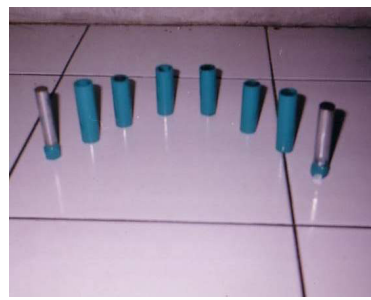

Gambar 6. Alat Pencetak Batubara

\section{HASIL PENELITIAN DAN PEMBAHASAN}

\section{Sifat-sifat bahan dasar}

Untuk mengetahui sifat sifat bahan dasar dilakukan penelitian di laboratorium Fakultas Kehutanan, UGM

Tabel 4.1 Sifat-Sifat Bahan Dasar

\begin{tabular}{ccc}
\hline Sifat & Sekam Padi & Arang Kayu \\
\hline Kadar air (\%) & 9,01 & 6,86 \\
Kadar Abu (\%) & 20,71 & 4,09 \\
Kadar Karbon (\%) & 3,64 & 52,35 \\
Volatile Matter (\%) & 66,64 & 36,69 \\
Nilai Kalor (Kal/Kg) & 3285,880 & 6987,723 \\
Kadar Oksigen ( \% ) & 2.1 & 2.6 \\
\hline
\end{tabular}

\section{Pengaruh Komposisi Campuran terhadap Massa yang Tertinggal dan Laju Pembakaran}

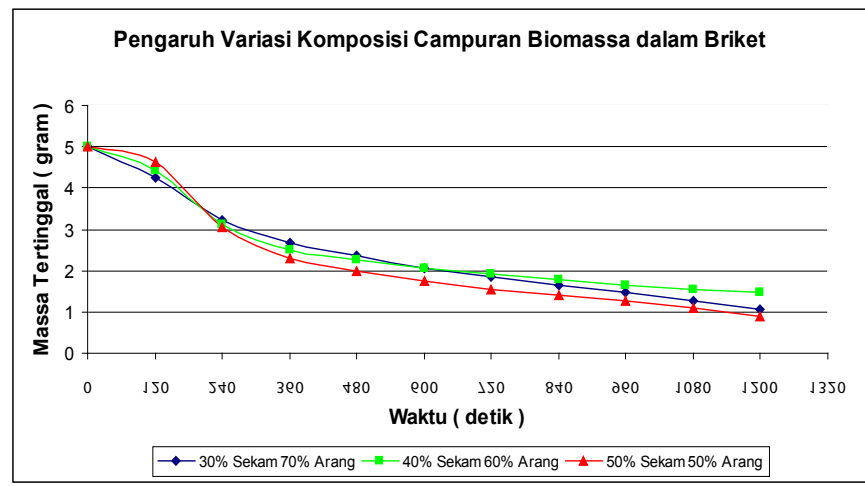

Gambar 7. Grafik hubungan massa yang tertinggal dengan waktu sebagai pengaruh variasi komposisi campuran dari biomassa dengan kecepatan udara $0,3 \mathrm{~m} / \mathrm{s}$ 


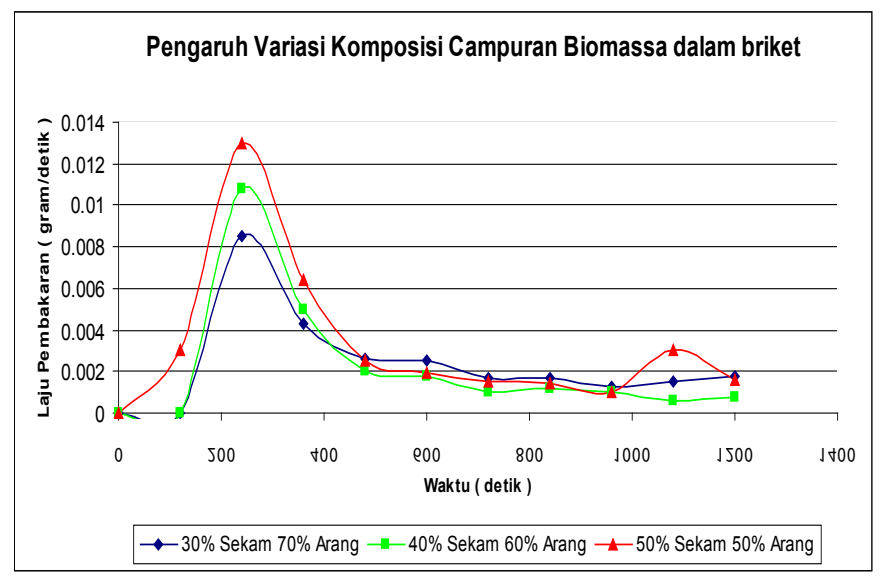

Gambar 8. Grafik pengaruh komposisi campuran terhadap laju pembakaran

Dari grafik diatas dapat dilihat bahwa laju pembakaran paling cepat adalah pada komposisi 50\% sekam padi : 50\% arang kayu, hal ini dipengaruhi oleh kandungan volatile matter biobriket. Semakin banyak kandungan volatile matter maka semakin mudah untuk terbakar dan menyala.

\section{Pengaruh Komposisi Campuran Terhadap Temperatur Pembakaran}

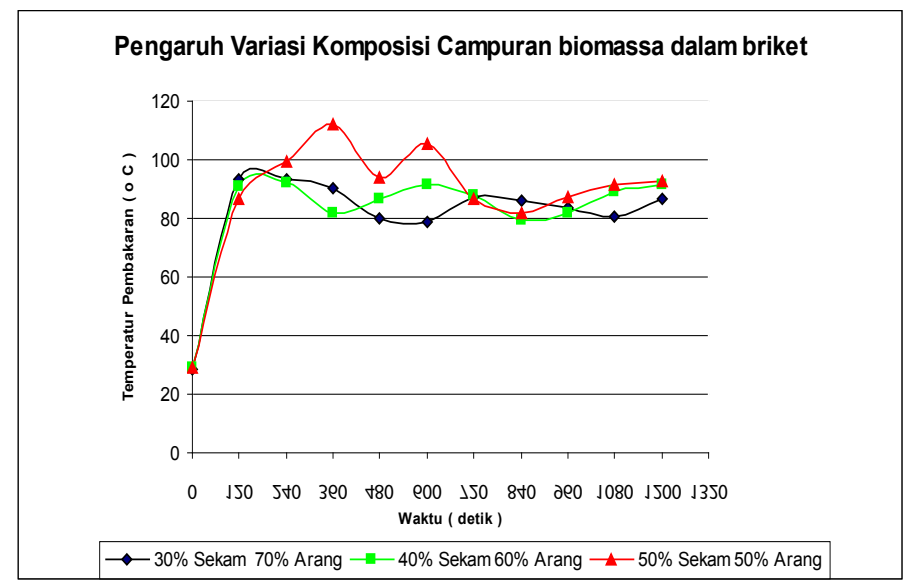

Gambar 9. Grafik Pengaruh Variasi Komposisi Terhadap Temperatur Pembakaran Pada Pembakaran Biobriket (Sekam padi : Arang kayu $=30 \%: 70 \%, 40 \%: 60 \%, 50 \%: 50 \%$ )

Dari grafik diatas dapat dilihat bahwa temperatur pembakaran tertinggi terjadi pada proses pembakaran biobriket dengan komposisi 30\% Sekam padi: 70\% Arang kayu, hal ini dipengaruhi oleh kandungan nilai kalor biobriket. Namun pencapaian suhu optimumnya lama. Semakin banyak kandungan nilai kalor maka laju pembakaran akan semakin lama.

\section{Nilai pembakaran tinggi ( HHV)}

Untuk menentukan atau menaksir besarnya nilai pembakaran tinggi (HHV) pada pembakaran bio briket digunakan Analisis Ultimasi dengan menggunakan rumus Dulong [4]:

$$
H H V=3.950 C+144.200\left(H_{2}-\frac{O_{2}}{8}\right)+9400 S \mathrm{kj} / \mathrm{kg}
$$

Rumus Dulong digunakan apabila nilai eksperimental dari pembakaran tidak tersedia. 


\section{Analisis ultimasi dari Arang kayu}

$\mathrm{C}=52,53 \%, \mathrm{H} 2=6,86 \%, \mathrm{O} 2=2,6 \%, \mathrm{~S}=0,14 \%, \mathrm{M}=28 \%, \mathrm{~A}=4,09 \%$

Untuk mengkonversi kesuatu basis batubara begitu diterima, faktor koreksi atau pelipatan adalah $(1-\mathrm{M}-\mathrm{A})=(1-28 \%-4,09 \%)=(1-0,28-0,04)=0,68$

Analisis Ultimasi begitu diterima menjadi :

$$
\begin{aligned}
& C=0,68 \times 52,53=35,59 \%=0,3559 \\
& \begin{array}{l}
H_{2}=0,68 \times 6,86=4,66 \%=0,0466 \quad O_{2}=0,68 \times 2,6=1,76 \%=0,0176 \\
S=0,68 \times 0,14=0,09 \%=0,0009 \\
H H V=33.950 C+144.200\left(H_{2}-\frac{O_{2}}{8}\right)+9400 S \\
=33.950(0,3559)+144.200\left(0,0466-\frac{0,0176}{8}\right)+9500(0,0009) \\
\quad=12082,805+144.200(0,0444)+8,46 \\
=12082,805+6402,48+8,46 \\
=18493,75 \mathrm{~kJ} / \mathrm{kg}
\end{array}
\end{aligned}
$$

\section{Analisis ultimasi dari sekam padi}

$\mathrm{C}=3,64 \%, \mathrm{H} 2=9,01 \%, \mathrm{O} 2=2,1 \%, \mathrm{~S}=0,13 \%, \mathrm{M}=42 \%, \mathrm{~A}=20,7 \%$

Untuk mengkonversi kesuatu basis batubara begitu diterima, faktor koreksi atau pelipatan adalah $(1-\mathrm{M}-\mathrm{A})=(1-42 \%-20,7 \%)=(1-0,24-0,207)=0,55$

Analisis Ultimasi begitu diterima menjadi :

$$
\begin{aligned}
& C=0,55 \times 3,64=2,002 \%=0,02 \\
& H_{2}=0,55 \times 9,01=4,955 \%=0,049 \\
& O_{2}=0,55 \times 2,1=1,155 \%=0,011 \\
& S=0,55 \times 0,13=0,0715 \%=0,0007 \\
& \begin{aligned}
H H V= & 33.950 C+144.200\left(H_{2}-\frac{O_{2}}{8}\right)+9400 S \\
\quad= & 33.950(0,02)+144.200\left(0,049-\frac{0,011}{8}\right)+9500(0,0007) \\
\quad= & 679+144.200(0,048)+6,58 \\
= & 679+7047,054+6,58 \\
= & 7732,634 \mathrm{~kJ} / \mathrm{kg}
\end{aligned}
\end{aligned}
$$

HHV 50\% sekam padi $+50 \%$ arang kayu

$$
\begin{array}{ll}
\text { HHV sekam padi } & =7732,634 \\
\text { HHV arang kayu } & =18493,75
\end{array}
$$

Arang $50 \%=0,5 \times 18493,75=9246,317$

Sekam $50 \%=0,5 \times 7732,634=3866,317$

Total 50\%sekam $+50 \%$ arang $=13113,31$

jadi nilai HHV sekam padi 50\% + arang kayu 50\% adalah $13113,31 \mathrm{~kJ} / \mathrm{kg}$.

HHV $40 \%$ sekam padi $+60 \%$ arang kayu 
ISSN: 1411-4348

$\begin{array}{ll}\text { HHV sekam padi } & =7732,634 \\ \text { HHV arang kayu } & =18493,75\end{array}$

Arang $50 \%=0,5 \times 18493,75=9246,317$

Sekam50\% $=0,5 \times 7732,634=3866,317$

Total $50 \%$ sekam $+50 \%$ arang $=13113,31$

jadi nilai HHV sekam padi 40\% + 60\% arang kayu adalah 14189,3 kJ/kg

HHV 30\% sekam padi $+70 \%$ arang kayu

HHV sekam padi $\quad=7732,634$

HHV arang kayu $=18493,75$

Sekam $40 \%=0,4 \times 7732,643=3093,05$

Arang $60 \%=0,6 \times 18493,75=11096,25$

Total $40 \%$ sekam $+60 \%$ arang $=14189,3$

Jadi nilai HHV sekam padi 30\%+ arang kayu 70\% adalah $15265,416 \mathrm{~kJ} / \mathrm{kg}$

Dari perhitungan diatas dapat diambil kesimpulan bahwa bio briket dengan campuran $30 \%$ sekam padi dan $70 \%$ arang kayu mempunyai nilai pembakaran tinggi yang besar sedangkan nilai pembakaran tinggi yang terkecil terdapat pada biobiket dengan campuran $50 \%$ sekam padi dan 50\% arang kayu, hal tersebut disebabkan oleh tingginya kandungan nilai kalor pada arang kayu hal tersebut dapat dilihat dalam tabel dibawah ini,

Tabel 4.2 kandungan nilai HHV

\begin{tabular}{cc}
\hline Campuran biobriket & Nilai HHV ( kJ/kg) \\
\hline Sekam 50\%- Arang 50^\% & 13113,31 \\
Sekam 40\%- Arang 60\% & 14189,3 \\
Sekamk 30\%-Arang 70\% & 15265,41 \\
\hline
\end{tabular}

\section{Polutan Pada Pembakaran Bahan Bakar}

Untuk mengetahui kandungan polutan yang terdapat pada pembakaran biobriket dilakukan penelitian di laboratorium Tehnik Mesin UGM.

Tabel 4.3 Polutan Pada Pembakaran Biobriket

\begin{tabular}{cccc}
\hline Komposisi & \multicolumn{3}{c}{ Jenis Polutan } \\
\cline { 2 - 4 } Sekam padi : Arang kayu & HC (\%) & CO (\%) & NO $_{\mathbf{2}}(\mathbf{\%})$ \\
\hline $30 \%: 70 \%$ & 3000 & 15 & 290 \\
$40 \%: 60 \%$ & 3100 & 70 & 280 \\
$50 \%: 50 \%$ & 3800 & 45 & 320 \\
\hline
\end{tabular}

Dari tabel diatas dapat dilihat bahwa semakin besar prosentase biomass pada biobriket maka kandungan emisi polutan $\mathrm{HC}, \mathrm{CO}$ dan $\mathrm{NO}_{2}$ semakin berkurang. Dari ketiga variasi komposisi tersebut dapat disimpulakan bahwa biobriket yang paling rendah polutannya adalah biobriket dengan komposisi Sekam padi 30\%: 70\% arang kayu.

\section{KESIMPULAN}

1. Laju pembakaran biobriket paling cepat adalah pada komposisi $50 \%$ sekam padi : $50 \%$ arang kayu. Hal ini dipengaruhi oleh kandungan volatile matter. Semakin banyak kandungan volatile matter suatu biobriket maka semakin mudah biobriket tersebut 
terbakar, sehingga pembakaran semakin cepat.

2. Bio briket dengan tingkat polusi terendah adalah pada komposisi $30 \%$ sekam padi : $70 \%$ arang kayu. Semakin banyak kandungan karbon suatu biobriket maka semakin banyak kandungan arang kayu pada biobriket akan menurunkan emisi polutan HC

3. Penggunaan biobriket untuk kebutuhan sehari-hari sebaiknya digunakan biobriket dengan perbandingan komposisi 30\% sekam padi : 70\% arang kayu

4. Bio briket dengan campuran $30 \%$ sekam padi dan $70 \%$ arang kayu mempunyai nilai pembakaran tinggi yang besar sedangkan nilai pembakaran tinggi yang terkecil terdapat pada biobiket dengan campuran 50\% sekam padi dan 50\% arang kayu

\section{DAFTAR PUSTAKA}

[1] Goutara, Semaugat ketaran, Depdikbud 1980, "Petunjuk Praktek Pengolahan Hasil Pertanian 3".UGM

[2] Joko, S, 2005, "Pengolahan Sampah Kota menjadi biobriket sebagai salah satu bahan bakar alternative", UMS.

[3] Edi Soenarjo, Djoko S Damarjati, Mahyuddin Syam. Pusat Penelitian dan Pengembangan Tanaman Pangan Bogor,1991, ” PADI (buku 3)", UGM

[4] Babcock \& Wilcox, S.C. Stultz and J.B.Kitto, 1992, "STEAM its generation and use" 